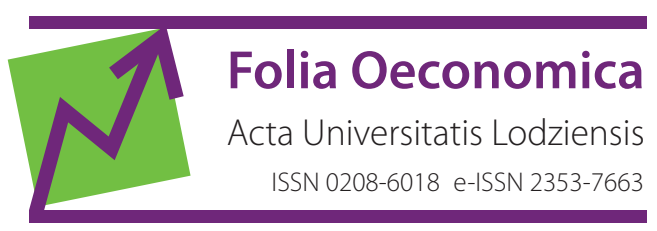

www.czasopisma.uni.lodz.pl/foe/

6(351) 2020

DOI: https://doi.org/10.18778/0208-6018.351.04

\title{
Justyna Danielewicz
}

University of Łódź, Faculty of Management, Department of City and Regional Management

Łódź, Poland, justyna.danielewicz@uni.lodz.pl

\section{Integrated Management of Metropolitan Areas in Romania}

\begin{abstract}
The rapid urbanisation of the world leads, among others, to dynamic development of metropolitan areas. The functional relationships between territorial units which make up a metropolitan area mean that the preparation of economically, spatially and environmentally coherent strategies needs to be coordinated at the metropolitan level in order to prevent negative effects of metropolisation and to ensure sustainable development of such an area. This in turn requires that the approach towards managing development shifts in favour of governance and integrated strategies. The paper aims at assessing whether the integrated planning and management is used in metropolitan areas in Romania. The desk research method was applied to analyse Romanian legislation for metropolitan areas, integrated strategies for the development of metropolitan areas and reports on their implementation. Interviews with representatives of selected associations of metropolitan areas provided additional valuable insight.
\end{abstract}

Keywords: governance, metropolitan areas, integrated planning and management, Romania

JEL: R58, R52, R11 


\section{Introduction}

Contemporary processes of globalisation and the related metropolisation cause fundamental changes in the form, structure, and organisation of cities (Solecki, Leichenko, 2006: 8). The process of metropolisation reconfigures space. From the spatial point of view, there is a noticeable tendency of the population to realign within and around large cities or metropolises. From the functional point of view, there is a tendency to concentrate activity within large cities or metropolises.

As the population grows in the surrounding areas, especially due to urban sprawl and the influx of people from other locations, the geographical and administrative boundaries of cities become insufficient for the purpose of defining the emerging urban areas. This expansion is driven by the broad endogenous local process of economic development which forces communities to gather around the urban centre that acts as a growth pole, in order to increase the level of competitiveness. Metropolitan development is therefore an administrative and economic challenge to the management and coordination of a wider range of resources.

Cities and metropolitan areas are, on the one hand, the "engines" of economic development where jobs, business, and higher education are concentrated. They are generally more productive than smaller urban agglomerations and rural areas. This is due to the territorial capital concentrated in their area, which includes, among others, a higher level of human capital. The larger the metropolitan area, the higher the profile of secondary education and the more talented its inhabitants, which in turn translates into a higher level of productivity. Agglomeration benefits or positive externalities related to the size of the metropolis are another reason for greater productivity. According to OECD estimates, agglomeration benefits are responsible for increasing the productivity of residents by 2 to 5 percent as the city's population doubles (Combes, Duranton, Gobillon, 2011). 75\% of Europe's population live in cities and around $85 \%$ of GDP is generated in urban areas. Thus, the prosperity prospects of most countries are largely determined by metropolitan areas, which means that effective metropolitan governance is of national importance (Ahrend et al., 2017). On the other hand, metropolitan areas are the site of significant problems related to social cohesion and environmental sustainability. Living in the city is conducive to achieving economies of scale and is inextricably linked with the benefits achieved by providing public services such as hospitals, schools, and universities. However, living in the city is also associated with a number of problems and negative effects. A particular problem faced by metropolitan areas is rapid suburbanisation and urban sprawl. This, in turn, has environmental implications. Cities produce countless amounts of toxic pollutants and greenhouse gases, consume enormous amounts of non-renewable fuels, and burn and store the majority of their waste (Blowers, Pain, 1999). Europe's cities are responsible for $80 \%$ of energy consumption and $80 \%$ of greenhouse gas emissions. Therefore, they 
face the problem of climate change. The challenges to the sustainable development of cities are also posed by the increase in individual consumption and ineffective use of natural resources, as well as the new forms of development which result in the emergence of socially divided, unfair and segregated areas (Cook, Swyngedouw, 2012: 1960). Environmental problems are a typical example of negative externalities and a consequence of the current consumption patterns and lifestyle choices that lead to the abuse of natural resources, the destruction of ecosystems and overpopulation of open areas (Ambruosi et al., 2010: 321).

The fact that the middle and upper classes are moving out of the metropolitan centre increases the intensity of individual commutes. This in turn causes an increase in noise, air pollution and traffic congestion.

Threats to sustainable development result not only from the environmental issues but also from social problems. In metropolitan areas, income inequalities and the progressing impoverishment of the disadvantaged are clearly visible, which in turn leads to social polarisation and segregation, and consequently, to spatial segregation. Districts of wealth and poverty are created in cities. This process is often accompanied by cultural and ethnic segregation, which in turn leads to social exclusion. Unemployment and scarcity of housing are the problems that plague the less affluent residents. The development of metropolitan areas is also often accompanied by an increase in crime and various types of pathologies.

A coordinated management approach is necessary to overcome these challenges. Metropolitan areas are functional units created by a large, complicated, and functionally coherent urban complex, the essential feature of which is the presence of metropolitan functions and functional connections. This cluster constitutes one economy and one labour market, usually under multiple local government jurisdictions. Any metropolitan area includes a number of autonomous territorial units with borders defined by the historical locations of towns and villages. These administrative structures are incapable of fully meeting the challenges of economic and social realities in large urban agglomerations. Although each administrative unit is managed by an independent local authority, one cannot overestimate the importance of the functional connections between individual communes and the central city in the metropolitan area which allow the inhabitants of nearby towns to benefit from easy access to the city's employment market, cultural, educational and health care institutions, as well as its sports and recreational facilities. The clear discrepancy between the administrative borders within which municipalities function to meet the needs of their residents and the borders determined by functional relationships that reflect the actual area of influence of individual urban centres means that to ensure the effectiveness of actions taken by public authorities, it is necessary to implement integrated planning and management methods.

Another characteristic of metropolitan areas is diversity (Heinelt, Kübler, 2004). Metropolises are home to a wide variety of public, private, and social ac- 
tors who have varied interests and ideas about public urban issues. These actors attempt to participate in the identification and resolution of these issues. Therefore, metropolitan communities must develop governance mechanisms for the purpose of making decisions about the city and its policies, assimilating the existing groups of actors, and absorbing the complexity involved in governing these broad spaces (Brody, 2003; Portney, 2009).

Poor communication and coordination among local governments in metropolitan areas can have many negative consequences and result in missed opportunities. For example (World Bank Group, 2020):

1. Fragmentation of certain public services (particularly those that benefit all communities, such as public transport) results in higher costs and financing challenges for each local government.

2. Inefficiencies due to a lack of broad-based planning can also arise in such sectors as solid waste disposal and flood management.

3. Negative spillovers. Air pollution, flooding and crime do not respect jurisdictional borders.

4. Free ridership. For example, the core city may need to address such problems as congestion from its own resources without fair contributions from the neighbouring jurisdictions that benefit from the positive effects of the agglomeration.

5. Underutilisation of some land which may have a limited value locally but potentially carry a higher value from a regional perspective.

6. Disparity between parts of the metropolitan area, e.g. differences in local financial capacities, creating large differences in the quality of amenities and services.

Overcoming metropolitan problems requires coordination and cooperation of local authorities and other stakeholders operating in the metropolitan area. This coordination and cooperation can be of more or less formalised nature. Metropolitan authorities which form a part of local government are the most formalised form of management coordination in metropolitan areas, while various types of loose agreements, often informal ones, between stakeholders in a given metropolitan area are the least formalised form.

The aim of this study is to assess the extent to which an integrated approach to development management is used in the management of metropolitan areas in Romania, with particular emphasis on governance. Romanian metropolitan areas have been chosen as the case study because, on the one hand, they have developed dynamically in recent years, which causes a number of problems (mentioned above) and requires changes in the approach to management, and on the other hand, there is little literature on the management of metropolitan areas in Eastern European countries where, since the end of the 1990s, we have witnessed the process of transition from a centrally planned economy to a market economy. The desk 
research method was applied to analyse Romanian legislation for metropolitan areas, integrated strategies for the development of metropolitan areas and reports on their implementation. Interviews with representatives of selected associations of metropolitan areas, conducted by e-mail between June and September 2020, provided additional valuable insight.

\section{Integrated development management in metropolitan areas}

Generally speaking, integrated development management can be understood as the combination of various activities at the level of a functional area and the creation of appropriate institutions to respond to problems in this area. Already in the Leipzig Charter, there are recommendations for cities that could be successfully applied to metropolitan areas. The Charter recommends that integrated development programmes for the entire functional area be devised. These implementation-oriented planning tools should (Karta Lipska..., 2007):

1) define a coherent vision and development goals for the entire area,

2) coordinate various territorial, sectoral, and technical plans and strategies, and ensure that the planned investments contribute to promoting the sustainable development of the functional area,

3) coordinate and spatially focus the use of funds by public and private sector actors, and

4) be coordinated at the local as well as urban level and involve citizens along with other partners who can significantly contribute to the shaping of the future quality of each area in economic, social, cultural and environmental terms. In the Pact of Amsterdam, the ministers responsible for urban affairs agreed that the complexity of urban challenges requires integrating various aspects of policies to avoid conflicting consequences and to increase the effectiveness of interventions in urban areas. Among priority topics of the EU urban agenda, there are ones that are key for the development of metropolitan areas (Urban Agenda..., 2016):

1. Effective urban governance, including citizens' participation and new models of governance.

2. Governance across administrative borders and inter-municipal cooperation: urban-rural, urban-urban and cross-border cooperation; a link with territorial development and the Territorial Agenda 2020 (well-balanced territorial development).

3. Sound and strategic urban planning; a link with regional planning and balanced territorial development, with a place-based and people-based approach.

4. An integrated and participatory approach. 
The purpose of integrated planning is not only the development of the city or metropolis as a whole, but also the development of its individual areas, especially the problem ones. Development is based not only on space transformation but also on solving social and economic problems. The integrated planning process defines the development needs of the city and its problem areas as well as the methods of addressing them in the urban space. The interests of residents and users of the space are analysed. The investments agreed on in this process are secured by their inclusion in detailed spatial development plans. As a consequence, such integrated city development planning precedes local law-making procedures.

Integrated development planning enables various entities to engage in comprehensive and multi-level activities in the form of partnership, and with a high degree of socialisation. It also makes controlling development processes possible. The essence of integrated development planning is a network of connections between various entities and the establishment of partnerships so development projects can be implemented. Thanks to integrated planning and management, cities can cope with the new challenges of quality spatial, social, and economic reconstruction.

Integrated management within a metropolitan area requires the widest possible cooperation of local government authorities, crossing the predetermined borders of administrative and competence divisions (Markowski, 2011). It is therefore not surprising to find that integrated planning has become established in planning studies during the past decades (Rotmans, van Asselt, Vellinga, 2000), along with policy integration (Geerlings, Stead, 2003; Albrechts, 2006; Hull, 2008; Stead, Meijers, 2009; Vigar, 2009; Candel, 2017; Tosun, Lang, 2017) and collaborative planning (Healey, 2010). It requires careful consideration of the dynamic systems of territorial connections that change both in time and space (Mantey, 2013).

We can distinguish five forms of integration:

1. Spatial integration. It is particularly important in metropolitan areas with strong anthropopression affecting the areas around the central city. In order to prevent the uncontrolled urban sprawl, it is necessary to implement an integrated spatial policy for the entire metropolitan area.

2. Functional (sectoral) integration. Due to the fact that social, economic, environmental, and spatial phenomena are closely interrelated, it is necessary to depart from a sectoral approach to development planning in order to create a coherent strategy for socio-economic and spatial development.

3. Time integration. When planning various activities, it is necessary to consider the schedule of their implementation within the entire functional area in order to reduce costs.

4. Stakeholder integration. Integrated planning and developments can be achieved through multi-level governance (Paulsson, 2020: 4), i.e. the cooperation of national, regional, and local public entities, business entities and social sector organisations, including the inhabitants themselves. Integrated planning of- 
ten denotes horizontal collaboration between different organisations within one policy field. In this context, collaborative planning is used to describe and acknowledge that governmental organisations cannot implement their plans or policies alone, but that they are interdependent on other actors in society (Healey, 2010). Integrated planning may also refer to vertical collaboration, where governmental organisations placed at different levels in the governance structure (e.g. local, regional and national) must coordinate their activities to achieve a common objective (Bulkeley, Betsill, 2005; Newig, Fritsch, 2009). Many scholars agree that while an administratively fragmented city can choose to govern and manage its parts individually, collaborative connections lead to better outcomes. Research has documented these advantages of cooperation and coordination (e.g., Morgan, Mareschal, 1999; Feiock, 2004). Scholars suggest that the vertical relationships between state governments and their municipalities and the horizontal relationships between local governments shape regional governance (Miller, Lee, 2009). Cities are an arena of constant interaction among diverse institutional actors leading to the development of agreements and contracts between them. For this cooperation to develop, the entities must have convergent priorities that cannot be achieved independently.

5. Financial integration. The development of metropolitan areas, which are the engines of development, requires the funds not only from the territorial units of the functional area, but also the funds from the central budget, European funds, and private resources. Public-private partnership is a key form of financial integration that determines the future competitiveness of individual metropolises.

It would be ideal to implement all forms of integration simultaneously. If an integrated approach to development planning is adopted at the metropolitan level, it is usually inevitable. For example, planning the development of housing zones in conjunction with the development of public transport infrastructure requires functional integration (transport, spatial and housing policy), stakeholder integration (local and regional authorities of individual municipalities, often also central authorities, public transport operators, developers), financial integration (public and private funds, including external funds), spatial integration (all planned investments included in the spatial development plans of individual territorial units), and temporary integration (construction of a road or a railway line across the territories of different communes should take place at the same time, as it will allow the authorities to select one contractor and reduce costs).

In practice, however, the possibilities for full integration tend to be limited.

The next part of this study focuses on the analysis of the approach to development management in Romanian metropolitan areas. Particular attention was paid to the forms of integration. 


\section{The place of metropolitan areas in the Romanian administrative system}

Romania is a democracy with a parliamentary cabinet system and a tripartite division of powers. Legislative power is held by the bicameral parliament - the Chamber of Deputies (lower house) and the Senate. Executive power is exercised by the government and the president, while the judiciary is held by courts and tribunals. The territorial division of the country includes:

1) 8 regions that do not have the status of administrative units and do not have legal personality. Their task is, above all, to coordinate the development of their constituencies. After Romania joined the European Union, they were classified as corresponding to the NUTS-2 level (Lege nr. 315, 2004);

2) 41 counties (Romanian județ) and one separate city (Romanian municipiu) - Bucharest;

3) 2,861 rural communes (Romanian comune) and 320 urban communes and towns.

Local organs of public administrations are local councils, mayors, and county councils (Guvernul României, 2019).

Territorial units with a large number of inhabitants and of high economic, social, political and scientific importance for the entire country or meeting the necessary conditions of development in these categories are classified as cities (at least 40,000 inhabitants) or as municipalities (min 10,000 population) (Lege nr. 100, 2007). Romanian legislation regulates the status of urban centres depending on the number of their inhabitants and their regional importance, and assigns them ranks accordingly (Lege nr. 351, 2001):

1. Rank 0 - Bucharest - the capital city, a commune of European importance;

2. Rank I- municipalities of national importance with a potential impact at the European level;

3. Rank II - communes of regional or county importance or communes that balance the network of locations (Romanian municipi);

4. Rank III - municipalities (Romanian orase).

A special status was given to the city of Bucharest, which has also the status of a county and is divided into six sectors with separate authorities and offices reporting to the city hall. The central government is represented by a prefect at the county level. ${ }^{1}$

The Romanian literature defines metropolitan areas as "spaces influenced by urban centres which perform macro-regional functions and whose population

1 See European Committee of the Regions, Romania, https://portal.cor.europa.eu/divisionpowers /Pages/Romania.aspx [accessed: 15.08.2020]. 
exceeds 1 million people" (Grigorescu et al., 2012: 45). Only the metropolitan area of Bucharest meets these conditions. The population of other large cities does not exceed 430,000, and their functional areas have approximately one million inhabitants. In order to support the development of metropolitan areas, the Romanian government has introduced provisions according to which a metropolitan area can be "formed by an association based on a voluntary partnership between the main urban centres and the adjacent urban and rural municipalities within $30 \mathrm{~km}$ from the central city which have developed cooperation on multiple levels" (Lege nr. 351, 2001). Cooperation in the form of an association of individual entities is the only institutionalised form of managing metropolitan areas allowed in Romania.

These provisions have been supplemented by other regulations aimed at improving organisation and management in metropolitan areas. Government Regulation No. 53/2002 on the framework status of the administrative-territorial unit states that metropolitan areas may be established only by administrative units located around Bucharest (rank 0) and by units located around first-rank cities (Ordonața nr. 53/2002).

The Administrative Code defines a metropolitan area as a cooperation structure with legal personality, established by Bucharest or the first rank cities and the rural areas in the immediate vicinity in order to implement joint development projects of local or regional importance or for the provision of shared public services. This structure is formed as an association. At the same time, it stresses that the legislative and executive authorities of each administrative-territorial unit within the area retain their local autonomy in accordance with the law (Guvernul României, 2019). Clearly, the central regulations say nothing about the delegation of any powers to the metropolitan level. These associations are legal persons, governed by private law, but have a special statute - the state acknowledges that they act in the interest of the public, and thus grants them the status of entities performing in the interest of the general public. The organ of the association is the board consisting of representatives of all administrative units in the area. The board may appoint a technical body whose operation should be financed from the association's own resources. The responsibilities of both bodies must be laid down in the association's statutes. The functioning of the association can be financed by contributions from its members and other sources, in accordance with the law (Lege nr. 215/2001, 2007).

\section{Development of metropolitan associations}

The first metropolitan associations started to form in 2004 when the Romanian government adopted the Regional Development Act. It stipulated that each of the seven regions (except Bucharest) would have its own growth pole to counterbalance 
the dominant position of the capital city (Lege nr. 315, 2004). The following cities of the 11 first-rank centres were selected: Cluj-Napoca, Iași, Timișoara, Constanța, Craiova, Brașov, and Ploiești. Bucharest and these centres, with their functional areas, account for 50 percent of the Romanian population and generate 75 percent of all business revenues in the country (Ionescu-Heroiu, 2016).

The possibility of acquiring European Union funds acted as a stimulus to develop metropolitan areas. According to the 2007-2013 National Strategic Reference Framework, the cities listed as growth poles could use up to $50 \%$ of the resources from the "Supporting sustainable urban development - potential growth poles" priority axis 1 . The condition for acquiring the funding was the formation of an inter-municipal association and the adoption of the Integrated Programme of Urban Development (IPUD). The funds were allocated to projects aimed at improving the quality of life and creating jobs through rehabilitation of urban infrastructure, improvement of services, including social services, as well as through the development of support systems for businesses and entrepreneurs. The projects implemented in Axis 1 of the Regional Operational Programme equalled ca 2.26 billion EUR, 621 million EUR of which were dedicated to just seven growth poles (Benedek, Varvari, Litan, 2019: 178).

One of the areas of the Integrated Programme of Urban Development, intervention 1.1, provided financial assistance for the development and implementation of IPUDs. The Strategic Framework for the Territorial Development of Romania 2030 calls for an integrated approach to the urban-rural relationship. It highlights the necessity to consolidate this relationship by approaching the development of rural areas not in opposition to the cities but in alignment with them, with particular emphasis on stimulating local partnerships and on integrated territorial planning (Hințea, Neamțu, 2014). Instead of implementing projects piecemeal, it was commonly agreed that generating synergies was far more productive. This policy required a multi-sectoral approach that focused not only on socio-economic development but also recognised the importance of spatial planning in ensuring sustainable urban development. Local authorities were encouraged not to think solely in terms of ROP funds when preparing integrated development plans and to focus primarily on the comprehensive, cross-sectoral development challenges faced by metropolitan areas (Growth..., 2013: 44).

Funds available under the ROP were the stimulus that led to the institutionalisation of metropolitan areas. The creation of inter-municipal associations had been possible since 2001 (Lege nr. 215/2001, 2007), but till 2007 only three areas had chosen this form of cooperation. However, after 2008 all seven metropolitan areas included in the growth poles policy created Inter-municipal Development Associations (IDA) and by the end of 2009 actually developed IPUDs (Table 1). The timeframe of those strategies spanned the period until the year 2015. 
Table 1. Metropolitan areas of growth poles in Romania

\begin{tabular}{|l|l|c|c|c|c|}
\hline \multicolumn{1}{|c|}{ Name } & $\begin{array}{c}\text { Administrative } \\
\text { units }\end{array}$ & $\begin{array}{c}\text { Year } \\
\text { of creation }\end{array}$ & $\begin{array}{c}\text { No of } \\
\text { employees } \\
\text { in MDA }\end{array}$ & $\begin{array}{c}\text { Population } \\
\mathbf{( 2 0 1 6 )}\end{array}$ & Area (km²) \\
\hline Iași Metropolitan Area & $\begin{array}{l}21 \text { communes, } \\
1 \text { county }\end{array}$ & 2004 & 7 & 472.733 & 808 \\
\hline $\begin{array}{l}\text { Braşov Metropolitan } \\
\text { Area }\end{array}$ & $\begin{array}{l}18 \text { communes, } \\
1 \text { county }\end{array}$ & 2005 & 25 & 473.470 & $1,368.58$ \\
\hline $\begin{array}{l}\text { Constanța } \\
\text { Metropolitan Area }\end{array}$ & $\begin{array}{l}16 \text { communes, } \\
1 \text { county }\end{array}$ & 2007 & 14 & 500.000 & 1013,5 \\
\hline $\begin{array}{l}\text { Cluj-Napoca } \\
\text { Metropolitan Area }\end{array}$ & 19 communes & 2008 & n. a. & 417.552 & $1,537.54$ \\
\hline $\begin{array}{l}\text { Craiova Metropolitan } \\
\text { Area }\end{array}$ & 24 communes & 2009 & 3 & 394.646 & 1498,62 \\
\hline $\begin{array}{l}\text { Ploiești Metropolitan } \\
\text { Area }\end{array}$ & 14 communes, \\
1 county & 2009 & 8 & 302.462 & 478 \\
\hline $\begin{array}{l}\text { Timișoara } \\
\text { Metropolitan Area }\end{array}$ & $\begin{array}{l}27 \text { communes, } \\
1 \text { county }\end{array}$ & 2009 & n. a. & 468.162 & 2439,12 \\
\hline
\end{tabular}

Source: own elaboration

The seven Integrated Urban Development Plans (IPUDs) are remarkably similar in terms of structure since all the local authorities involved benefited from a great deal of technical expertise, know-how transfer and training from the central government during the drafting process. It explains why these plans follow a similar format. In order for the IPUDs to be an effective planning instrument, their provisions need to be reflected to a certain extent in the local development strategies (Hințea, Neamțu, 2014). In practice, most ROP-financed investments were concentrated in city centres and did not help integrate larger metropolitan areas into a coherent, functional, and development-oriented urban ecosystem. Only $0.7 \%$ of the funds were distributed by the associations, which clearly suggests their symbolic status and poor capacity for integrated management. Due to the limited sources of IDA financing, these resources are frequently insufficient to coordinate metropolitan projects, which results in the inconsistent effectiveness of the associations. In fact, only two of these associations - the Constana and Braşzov metropolitan areas - have been able to engage in the actual implementation of projects that reach outside the central cities. The process has led to a significant improvement in infrastructure and public services. In addition, it has promoted greater productivity and internal migration (Cristea, Ionescu-Heroiu, 2017). However, there are also some associations that have a purely theoretical aspect and do not work in practice (e.g. Cluj-Napoca). The areas of primary focus for the associations that seek to coordinate activities at the metropolitan level are:

1) integrated development planning;

2) sustainable public transport systems within the whole metropolitan area;

3) integrated economic development; 
4) attracting new investments and increasing access to resources;

5) improvement and development of transport, telecommunications, and energy infrastructure;

6) reducing disproportions between towns in the metropolitan area;

7) development of human resources, increasing the level of employment and combating social exclusion and social imbalance;

8) development of new residential areas;

9) development and improvement of public services;

10) environmental protection and sustainable development;

11) development of tourism and the service sector;

12) joint promotion.

At the same time, it should be noted that these IPUDs' provisions are rarely reflected in the implementation of specific projects.

Land development planning is one of the areas where a more integrated approach is needed, given the fact that all of the seven cities have been sprawling toward the neighbouring rural communities, and their mutual interdependencies have grown. Romanian legislation provides metropolitan plans for major cities and their municipalities that should contain solutions to problems and strategies for metropolitan areas. These regulations say nothing though about how these plans should relate to the plans of other areas (Enhanced..., 2013: 53). The spatial planning system provides for plans for metropolitan areas but their implementation is certainly limited. There is no legal framework granting planning mandates to inter-municipal development associations that currently manage metropolitan areas. Moreover, the research conducted in communes in metropolitan associations shows that both urban and rural communities are hesitant to name spatial planning as one of the areas where cooperation can occur. They believe that spatial planning issues should be handled locally, without the interference from other communities (Hințea, Neamțu, 2014).

\section{Governance in metropolitan areas}

Governance in metropolitan areas is complex. The adoption of the growth poles policy has resulted in the obligation to appoint a coordinator in each metropolitan area to supervise both the development and implementation of an integrated development plan. The coordinator's duties include: establishing stable cooperation and consultations, at both the central and local level, with institutions involved in the development and implementation of the integrated development plan; participation in working meetings during the development and implementation of the integrated development plan; participation in monitoring the implementation schedule of the integrated development plan; and preparation of regular reports and information 
documents on the state of implementation of the integrated development plan. The coordinator functions within the Regional Development Agency (RDA) assigned to the region with the growth pole in question (Hotărârea nr. 1513, 2008).

Part of governance is the requirement for each metropolitan area to conclude tripartite contracts with the Ministry of Regional Development and Public Administration, the Ministry of Economy and Finance (via the Agency for Coordination of Structural Instruments) and the Regional Development Agency (Growth..., 2013: 26). All seven metropolitan areas signed such contracts in 2009. Their scope is in each case remarkably similar (the same). Their role is to coordinate the rights and obligations of the parties involved, and to establish a procedure for interinstitutional cooperation with regard to the selection and duties of pole coordinators. The contracts define the procedure of coordinators' recruitment, their powers, and sources of funding (Hotărârea nr. 1513, 2008). Coordinators were selected from among RDA employees, town hall employees or employees of other local institutions. The arrangements adopted in these contracts apply also to the area leader, the President of the Inter-Communal Development Association (IDA), a body established at the metropolitan level. The Growth Pole Coordinator is committed to establishing an ongoing cooperation and consultations with the Growth Pole Leader. Formally, there is no hierarchical relationship between the coordinator and the area leader (Figure 1).

At the central level, the Ministry of Economy and Finance and the Ministry of Regional Development and Public Administration, in charge of guidelines, cooperate with the Growth Pole Coordinator, namely the Regional Development Agency. The Agency is the executive body of the economic and development regions created in 1998. The agency cooperates with the Metropolitan Development Association.

There are, however, no further records regarding the role of associations in these agreements, although they are generally responsible for the implementation of projects and policies at the metropolitan level, and their role and powers should be defined in clear terms.

Due to the fact that the governance system in metropolitan areas is strictly defined by law, there are no significant differences in the manner of institutionalisation. The differentiating feature is the size and functioning of technical bodies, which is directly associated with a varying number of permanent MDAs' employees. This number ranges between three and twenty five.

Independently of metropolitan associations, municipalities in metropolitan areas form numerous single-target associations for inter-municipal development, with a varying number of members. In the case of public transport, the association is usually formed by the city and the surrounding towns and villages whose residents commute to work in the city. In the case of waste management, the association is sometimes even larger than the territorial boundaries of the metropolitan area, often involving the entire county. 


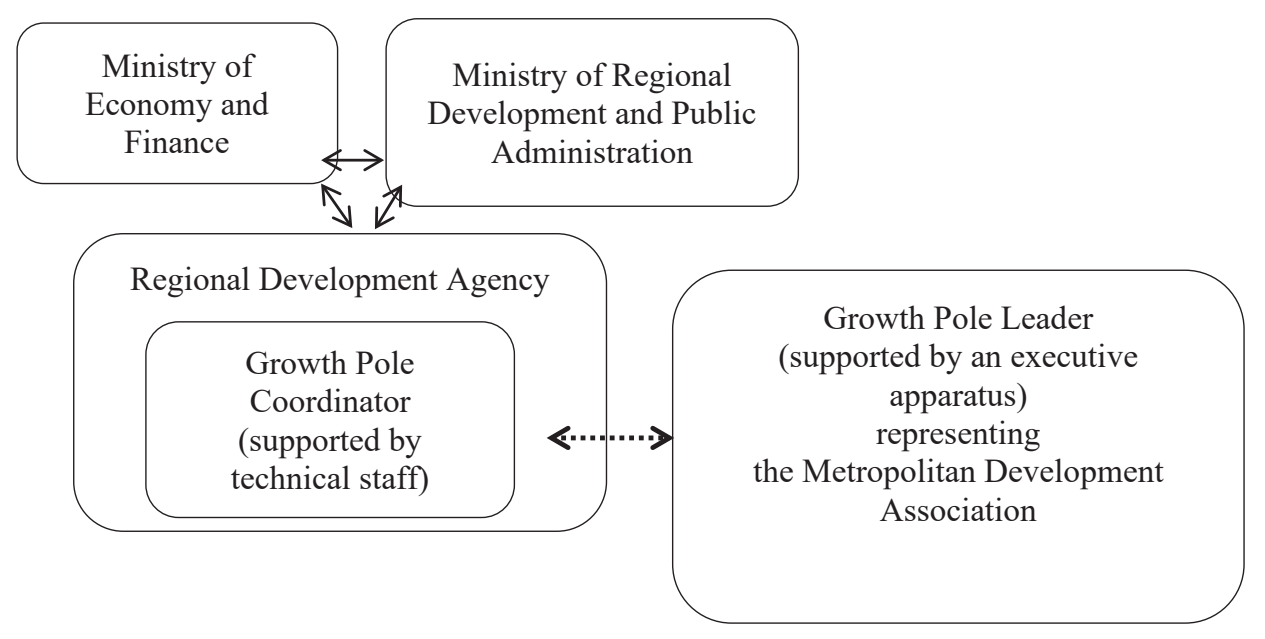

Figure 1. Governance structure in Romanian metropolitan areas.

Source: World Bank, 2013

\section{Conclusions}

The analyses of the World Bank show that metropolitan areas in Romania do not function properly. There are only a few areas that have a functional public transport system (e.g. Cluj-Napoca), only a few cities have zoning plans for metropolitan areas (e.g. Braov, Craiova), and even fewer have managed to implement projects at the metropolitan level (e.g. Constana) (Ionescu-Heroiu, 2016).

The barriers to their development are complex and include:

1. No clear legal framework. The regulations regarding metropolitan areas are scattered among many legal acts. The role and powers of metropolitan areas are poorly explained in various regulatory documents related to the policy of growth poles and they overlap with the powers of other tiers of public administration. There are no separate regulations governing the functioning, characteristics, and financing mechanisms of metropolitan development associations (Growth..., 2013: 86). Currently, their functioning and funding is viewed on a par with those of any other association. The lack of specific legislation also makes it difficult for territorial units to use other methods of financing, such as funds intended for the public sector or fiscal instruments. Also, the possibility of delegating powers by territorial entities is severely limited. Currently, MDAs can only play a symbolic role, providing a platform for networking and cooperation between local governments, without any clearly defined tasks, which considerably weakens their status. 
2. Lack of accountability and transparency due to the fact that MDAs are not governed by directly elected bodies, difficult decision-making as each decision must be approved by all legislative bodies of the partnering entities. There are also no mechanisms to incentivise proper management of associations. They mostly employ public officials for whom their work in the association is an additional and relatively poorly remunerated obligation.

3. Lack of financial resources and dependence on transfers from other tiers of government; over-dependence on European money for financing infrastructure projects, which means diminishing the importance of priorities for which such financing is not available. Moreover, investment needs of the growth poles exceed financial capacities of local governments. In the absence of central government's support for new projects, which coincides with increased expectations of residents regarding the quality of public services, leisure, entertainment, and promotion of healthy life style, mayors often prefer to focus solely on issues that directly affect their constituencies. Poor central government incentives limit the ability of local administrations to adopt an integrated metropolitan development approach.

4. Dominance of the central city, a lack of trust and no tradition of cooperation all result in poor relations between the central city and the surrounding units. While integrated development plans for growth poles should also cover peri-urban areas, the number and variety of projects targeting suburban towns is meagre compared to those planned for urban centres. Oftentimes rural communities are treated as junior partners because they lack the resources to co-finance truly metropolitan projects. It is therefore difficult for rural communities to see the city as the generator of a spill-over effect in terms of welfare and development opportunities. A lack of trust among the partners forming the associative structures sometimes stops large projects because not all parties can identify the advantages to be derived from the cooperation.

5. The voluntary character of the association. In practice, some metropolitan areas exclude certain communities in the functional zones surrounding growth poles.

6. Delimitation of metropolitan areas. Narrowing the analysis and intervention to the area with a radius of $30 \mathrm{~km}$ around a central city does not account for the fact that major urban agglomerations tend to have larger functional economic areas. Therefore, there is a need for a comprehensive policy, inclusive of growth poles within a broader spatial context.

7. Terms of office for authorities in metropolitan associations. The mayors who are members of the association can agree on a set of common goals and introduce measures to achieve these goals, but new elections can bring about changes in management and give rise to a new set of problems.

8. Limiting governance to cooperation between local governments and the central government. Other public sector entities as well as private and non-gov- 
ernmental stakeholders should be included in this process, and communication as well as public participation should be promoted.

9. Overcoming the limitations listed above is necessary in order to increase the effectiveness of metropolitan areas. They are struggling with a number of problems related to the uncontrolled urban sprawl and a growing demand for public services in suburban areas. It is therefore crucial that a clear legal framework for the metropolitan area management system is developed, not only to ensure functional spatial planning at the metropolitan level but also to increase implementation capacity. This legislation should separate the MDAs from the general category of non-governmental organisations. It should define how local/county powers are transferred to the association, clarify funding mechanisms (including fiscal powers), and allow metropolitan associations to access the funds that are currently available only to the public sector beneficiaries. The process of local economic development can no longer be envisioned without cooperation with the neighbouring communities. ${ }^{2} \mathrm{Sev}-$ eral cities are already short of land for large future projects and need to work closely with the adjacent communities to identify suitable investment locations. There is also the negative financial impact of commuters from suburban communities who use the services provided by the city but at the same time also take advantage of the lower taxes and lower real estate prices in the neighbouring rural communities. Interdependencies between the city and the suburban communities need to be acknowledged by both parties, and joint solutions need to be found.

Metropolitan areas can benefit from integrated management in the following ways:

1) more effective implementation of tasks through cooperation between various entities to make decisions and reach an agreement as to the method of their implementation;

2) efficient delivery of public services;

3) coordination of tasks at the supra-local level enabling the creation of a clear framework of development;

4) the ability to perform tasks that would not be possible for individual units;

5) an increase in social capital in a given area;

6) improving the quality of life.

It should be remembered that not all types of metropolitan problems can be solved through cooperation and a bottom-up management approach. The state also has a significant role to play here in promoting and stimulating integration of metropolitan management, using all the available instruments.

2 The experiences of the countries of Western and Central Europe may help in developing solutions favourable to metropolitan areas in Romania (cf.: Danielewicz, 2013). 


\section{References}

Ahrend R., Kim S. J., Lembcke A.C., Schumann A. (2017), Why Metropolitan Governance Matters and How to Achieve It, [in:] D. Gómez-Álvarez, R. Rajack, E. López-Moreno, G. Lanfranchi (eds.), Steering the metropolis: metropolitan governance for sustainable urban development, IDB, Washington, pp. 51-60.

Albrechts L. (2006), Bridge the gap: From spatial planning to strategic projects, "European Planning Studies", vol. 14, no. 10, pp. 1487-1500.

Ambruosi C.S., Baldinelli G.M., Cappuccini E., Migliardi F. (2010), Metropolitan Governance: Which Policies for Globalizing Cities?, “Transition Studies Review”, no. 17, pp. 320-331.

Benedek J., Varvari Ş., Litan C.M. (2019), Urban Growth Pole Policy and Regional Development: Old Wine in New Bottles?, [in:] T. Lang, F. Görmar (eds.), Regional and Local Development in Times of Polarisation. New Geographies of Europe, Palgrave Macmillan, Singapore, pp. 173-195.

Blowers A., Pain K. (1999), The unsustainable city?, [in:] S. Pile, C. Brook, G. Mooney (eds.), Unruly Cities? Order/Disorder, Routledge, London, pp. 247-298.

Brody S. D. (2003), Measuring the effects of stakeholder participation on the quality of local plans based on the principles of collaborative ecosystem management, "Journal of Planning Education and Research", no. 22, pp. 407-419.

Bulkeley H., Betsill M. (2005), Rethinking Sustainable Cities: Multilevel Governance and the 'Urban' Politics of Climate Change, "Environmental Politics", vol. 14, no. 1, pp. 42-63.

Candel J.J.L. (2017), Holy Grail or inflated expectations? The success and failure of integrated policy strategies, "Policy Studies", vol. 38, no. 6, pp. 519-552.

Combes P.P., Duranton G., Gobillon L. (2011), The identification of agglomeration economies, OECD, Paris, pp. 253-266.

Cook I.R., Swyngedouw E. (2012), Cities, social cohesion and the environment: towards a future research agenda, "Urban Studies", vol. 49, no. 9, pp. 1959-1979.

Cristea M., Ionescu-Heroiu M. (2017), Turning Romania's secondary cities into engines of growth, https://blogs.worldbank.org/europeandcentralasia/turning-romania-s-secondary-citiesengines-growth [accessed: 14.09.2020].

Danielewicz J. (2013), Zarządzanie obszarami metropolitalnymi wobec globalnych procesów urbanizacji, Wydawnictwo Uniwersytetu Łódzkiego, Łódź.

Enhanced Spatial Planning as a Precondition for Sustainable Urban Development (2013), http:// documents.worldbank.org/curated/en/782491468296462975/pdf/Full-report.pdf [accessed: 22.08.2020].

European Committee of the Regions, Romania, https://portal.cor.europa.eu/divisionpowers/Pages /Romania.aspx [accessed: 15.08.2020].

Feiock C.R. (ed.) (2004), Metropolitan Governance. Conflict, Competition and Cooperation, Georgetown University Press, Washington.

Geerlings H., Stead D. (2003), The integration of land use planning, transport and environment in European policy and research, "Transport Policy", vol. 10, no. 3, pp. 187-196.

Grigorescu I., Mitrică B., Mocanu I., Ticană N. (2012), Urban Sprawl and Residential Development in the Romanian Metropolitan Areas, "Romanian Journal of Geography", vol. 56, pp. 43-59.

Growth Poles. The Next Phase (2013), http://documents.worldbank.org/curated/en /286101468105256650/pdf/Full-report.pdf [accessed: 25.08.2020].

Guvernul României (2019), Codul administrativ din 03 iulie 2019.

Healey P. (2010), Making Better Places: The Planning Project in the Twenty-First Century, Palgrave Macmillan, Basingstoke.

Heinelt H., Kübler D. (2004), Metropolitan governance in the 21st century. Capacity, democracy and the dynamics of place, Routledge, London. 
Hințea C., Neamțu B. (2014), Strategic Planning in the Framework of Metropolitan Areas in Romania: Going beyond the Requirements of the Law and Transforming it into an Effective Planning Tool, "The NISPAcee Journal of Public Administration and Policy", vol. VII, no. 2, pp. 71-97, https://doi.org/10.2478/nispa-2014-0004

Hotărârea nr. 1513/2008 privind completarea Hotărârii Guvernului nr. 998/2008 pentru desemnarea polilor de creștere și a polilor de dezvoltare urbană în care se realizează cu prioritate investiții din programele cu finanțare comunitară și națională, Monitorul Oficial, Partea I nr. 813 din 04 decembrie 2008.

Hull A. (2008), Policy integration: What will it take to achieve more sustainable transport solutions in cities?, "Transport Policy", vol. 15, no. 2, pp. 94-103.

Ionescu-Heroiu M. (2016), Metropolitan development is central to Romania's economic development, https://blogs.worldbank.org/europeandcentralasia/metropolitan-development-central -romania-s-economic-development [accessed: 15.08.2020].

Karta Lipska na rzecz zrównoważonego rozwoju miast europejskich, 2007, Lipsk.

Lege nr. 350 din 6 iunie 2001 privind amenajarea teritoriului și urbanismul, Monitorul Oficial nr. 373 din 10 iulie 2001.

Lege nr. 351 din 6 iulie 2001 privind aprobarea Planului de amenajare a teritoriului național - Secțiunea a IV-a Rețeaua de localități, Monitorul Oficial nr. 408 din 24 iulie 2001.

Lege nr. 315 din 28 iunie 2004 privind dezvoltarea regionala în România, Monitorul Oficial nr. 577 din 29 iunie 2004.

Lege nr. 100 din 19 aprilie 2007 pentru modificarea şi completarea Legii nr. 351/2001 privind aprobarea Planului de amenajare a teritoriului naţional - Secţiunea a IV-a - Reţeaua de localităţi, Monitorul Oficial nr. 284 din 27 aprilie 2007.

Lege nr. 215/2001, Monitorul Oficial, nr. 123 din 20 februarie 2007.

Mantey D. (2013), Zintegrowane zarzadzanie miastami i obszarami metropolitalnymi, "Infos", no. 4(141), pp. 1-4.

Markowski T. (2011), Funkcjonowanie gospodarki przestrzennej-założenia budowy modelu zintegrowanego planowania i zarzadzania, "Studia KPZK PAN", vol. CXXXIV, pp. 25-44.

Miller D. Y., Lee J.H. (2009), Making sense of metropolitan regions: A dimensional approach to regional governance, "Publius: The Journal of Federalism", vol. 41, pp. 126-145.

Morgan D.R., Mareschal P. (1999), Central-city/suburban inequality and metropolitan political fragmentation, "Urban Affairs Review", no. 34, pp. 578-595.

Newig J., Fritsch O. (2009), Environmental governance: Participatory, multi-level - and effective, "Environmental Policy and Governance", no. 19, pp. 197-214.

Ordonanța nr. 53/2002 privind Statutul-cadru al unității administrativ-teritoriale, Monitorul Oficial, Partea I nr. 633 din 27 august 2002.

Paulsson A. (2020), The city that the metro system built: Urban transformations and modalities of integrated planning in Stockholm, "Urban Studies", vol. 57, no. 14, pp. 2936-2955.

Portney K.E. (2009), Sustainability in American cities: A comprehensive look at what cities are doing and why?, [in:] D.A. Mazmanian, M.E. Kraft (eds.), Toward sustainable communities, MIT Press, Cambridge, pp. 227-254.

Rotmans J., Asselt M. van, Vellinga P. (2000), An integrated planning tool for sustainable cities, "Environmental Impact Assessment Review", vol. 20, no. 3, pp. 265-276.

Solecki W.D., Leichenko R.M. (2006), Urbanization and the Metropolitan Environment: Lessons from New York and Shanghai, "Environment: Science and Policy for Sustainable Development", vol. 48, no. 4, pp. 8-23.

Stead D., Meijers E. (2009), Spatial Planning and Policy Integration: Concepts, Facilitators and Inhibitors, "Planning Theory \& Practice", vol. 10, no. 3, pp. 317-332.

Tosun J., Lang A. (2017), Policy integration: Mapping the different concepts, "Policy Studies", vol. 38 , no. 6 , pp. 553-570. 
Urban Agenda for the EU. Pact of Amsterdam (2016), Amsterdam.

Vigar G. (2009), Towards an integrated spatial planning?, "European Planning Studies", vol. 17, no. 11, pp. 1571-1590.

World Bank (2013), Growth Poles. The Next Phase, Washington, https://openknowledge.worldbank .org/handle/10986/24488 [accessed: 27.08.2020].

World Bank Group (2020), International Practices of Metropolitan Governance A Compendium of Collaborative Arrangements in Metropolitan Areas, Washington.

\section{Zintegrowane zarządzanie rozwojem obszarów metropolitalnych w Rumunii}

Streszczenie: Zachodzące na świecie procesy gwałtownej urbanizacji prowadzą między innymi do dynamicznego rozwoju obszarów metropolitalnych. Powiązania funkcjonalne między jednostkami terytorialnymi wchodzącymi w skład obszaru metropolitalnego powodują, że w celu zapobiegania negatywnym skutkom metropolizacji i zapewnienia zrównoważonego rozwoju takiego obszaru należy koordynować na poziomie metropolitalnym przygotowanie spójnych gospodarczo, przestrzennie i środowiskowo strategii. To z kolei wymaga zmiany podejścia do zarządzania rozwojem w kierunku współrządzenia i zintegrowanego planowania rozwoju. Celem artykułu jest ocena, czy zintegrowane planowanie i zarządzanie jest stosowane w obszarach metropolitalnych Rumunii. W badaniach wykorzystano metodę desk research, w ramach której przeanalizowano rumuńskie ustawodawstwo dotyczące obszarów metropolitalnych, zintegrowane strategie rozwoju obszarów metropolitalnych oraz raporty z ich realizacji. Cennym uzupełnieniem informacji były wywiady z przedstawicielami wybranych stowarzyszeń obszarów metropolitalnych.

Słowa kluczowe: współrządzenie, obszary metropolitalne, zintegrowane planowanie i zarządzanie, Rumunia

JEL: R58, R52, R11

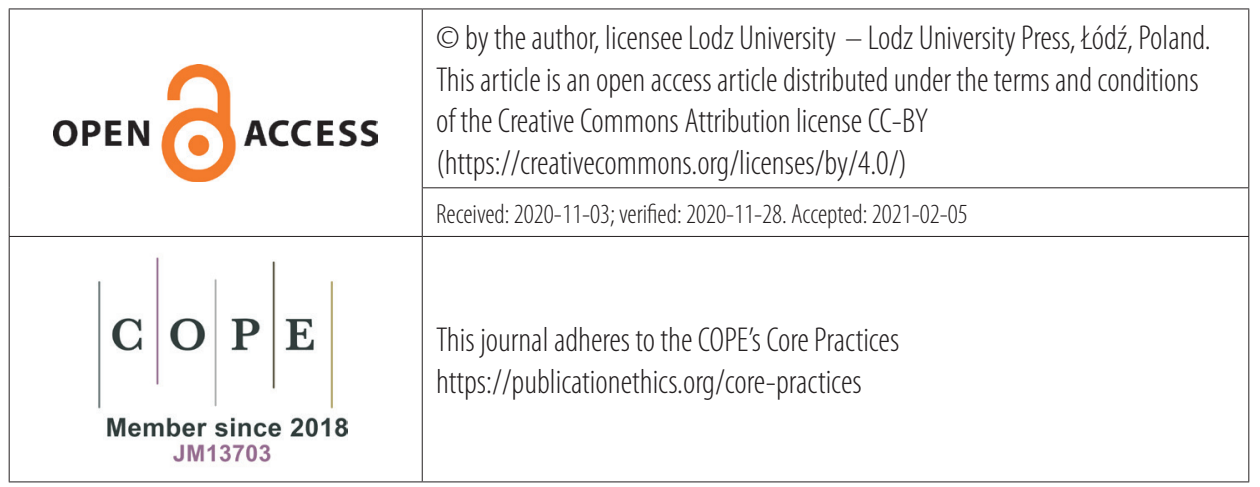

